TITLE:

\title{
Feasibility of improved slotted bolted connection for timber moment frames
}

AUTHOR(S):

Araki, Yoshikazu; Endo, Toshiki; Iwata, Manami

CITATION:

Araki, Yoshikazu ...[et al]. Feasibility of improved slotted bolted

connection for timber moment frames. Journal of Wood Science 2011, 57(3): 247-253

\section{ISSUE DATE:}

2011-06

URL:

http://hdl.handle.net/2433/143577

\section{RIGHT:}

The final publication is available at www.springerlink.com; This is not the published version. Please cite only the published version.; この論文 は出版社版でありません。引用の際には出版社版をご確認ご利用くだ さい。 
Note

\section{Feasibility of improved slotted bolted connection for timber moment frames}

Yoshikazu Araki*, Toshiki Endo, Manami Iwata

Department of Architecture and Architectural Engineering, Kyoto University, Katsura, Nishikyo, Kyoto 615-8540, Japan

*Corresponding author

Tel. +81-75-383-2924; Fax +81-75-383-2924; e-mail: araki@ archi.kyoto-u.ac.jp

\section{Key words}

Timber moment frame, Slotted bolted connection, Friction damper, Steel tube, Resin injection 


\section{Abstract}

This note examines the feasibility of an improved slotted bolted connection for timber moment frames. In the present connection, steel tubes are inserted into drill holes in glulam, and the steel tubes are fixed to the glulam with resin injection. Aluminum splice plates with curved slots, or curved elongated holes, are fastened mechanically by using high strength bolts that go through the steel tubes. Since the compression due to bolt tension is fully supported by the steel tubes, reduction of bolt tension due to shrinkage of glulam can be avoided. The use of slotted aluminum splice plates allows stable energy dissipation due to smooth sliding between the aluminum splice plates and the end surfaces of the steel tubes within the specified range of rotation angle. Through quasistatic cyclic loading tests of two connection specimens, it was demonstrated that stable and nearly rigid-plastic hysteresis loops were obtained whose equivalent viscous damping ratio was more than $30 \%$ in the ranges of rotation angle close to or over $1 / 50$ radian. Although further improvement is necessary, the experimental results demonstrate the feasibility and potential of the present connection. 


\section{Introduction}

The performance of timber connections under cyclic loading is one of the key factors that determine the overall seismic performance of a timber frame. A number of research works have been undertaken on the improvement of cyclic performance of timber connections. ${ }^{1-7}$ Hysteresis loops of conventional bolted timber connections are often characterized by pinching, or degradation of stiffness and strength under cyclic loading. Main sources of pinching are enlargement of bolt holes and/or inelastic bolt elongation. Pinching is undesirable because it leads to reduction of energy dissipating capacity. Furthermore, pinching reduces the lateral stiffness of a timber frame, which may require significant repair after a strong earthquake.

As an approach to avoid pinching, the concept of slotted bolted connection (SBC), originally developed as a friction damper for steel frames, was applied to timber connections. ${ }^{5,6}$ In SBCs, steel plates with and without slots, or elongated holes, are fastened by high strength bolts, and energy is dissipated by sliding between the steel plates. The application of SBCs to timber connections dates back at least to the work by Duff et al. ${ }^{5}$ Pinching remained in their SBCs, however, because steel plates were connected to glulam using conventional bolted connections. Leichti et al. ${ }^{6}$ developed improved SBCs for timber frames, and demonstrated that pinching can be prevented in the SBCs through quasistatic cyclic loading tests. Nevertheless, in their SBCs, steel plates were directly connected to glulam by using frictional resistance developed by bolt tension. Hence the reduction of bolt tension due to shrinkage of glulam may lead to significant reduction of energy dissipating capacity. ${ }^{7}$ Although the use of Belleville (cone disk) compression washers was proposed to avoid or minimize the reduction of bolt tension, its long term reliability is uncertain. 
Apart from the SBCs mentioned above, two types of friction connections for timber frames were developed ${ }^{8,9}$ which can avoid the reduction of bolt tension due to shrinkage of glulam. Tokuda et al. ${ }^{8}$ inserted steel tubes into oversized drill holes in glulam, and fixed them by injecting epoxy resin between the glulam and the steel tubes. Suzuki et al. ${ }^{9}$ pressed steel tubes into the holes whose diameter was slightly smaller than that of the steel tubes. In both connections, splice plates were fastened mechanically by high strength bolts that went through steel tubes. This way, the compression due to bolt tension can be fully supported by steel tubes, which makes the reduction of bolt tension negligible even in long term use. It was shown through monotonic loading tests that the failure modes of both connections were ductile. Nonetheless, pinching is unavoidable in these connections since no slots were provided to the splice plates.

The objective of this note is to examine the feasibility of an improved SBC for timber moment frames that combines the strengths of and eliminates the weaknesses of the SBCs and the friction connections mentioned above. This note reports the results of quasistatic cyclic loading tests performed to assess the performance of the present SBC.

\section{Materials and methods}

Figs. 1 and 2 illustrate the experimental setting. Douglas-fir glulam was connected to box section steel pipes using aluminum splice plates having curved slots. Cyclic loading was applied to the top of the glulam using a hydraulic actuator, while the box section steel pipes were fixed to the reaction floor. Fig. 3 shows schematically the initial and deformed configurations of the specimen. In Fig. 3, the curved slots predrilled in the splice plates are shown by light gray elongated circles, and the high-strength bolts going 
through the drill holes of the glulam are shown by black circles. As shown in Fig. 4, steel tubes were inserted into the holes drilled in the glulam, and epoxy resin was injected into the space between the steel tubes and the glulam. The aluminum splice plates were fastened mechanically to the glulam using high strength bolts that went through the steel tubes. Two specimens, named Specimens A1 and A2, were prepared for the tests. The differences between them were the numbers and locations of the steel tubes inserted in the glulam as shown in Fig. 5.

Fig. 6(a) shows the cut open specimen after the test. The details of the build up process were as follows.

1. A hole of $40 \mathrm{~mm}$ diameter was drilled, and about half of the drill hole was widened so that the diameter of the wider side of the drill hole was $45 \mathrm{~mm}$.

2. A steel washer was sandwiched by Steel tubes P1 and P2, whose outer and inner diameters were $34 \mathrm{~mm}$ and $25 \mathrm{~mm}$, respectively. They were bonded together using epoxy resin. The assembly of the steel washer and the steel tubes was inserted into the drill hole from the wider side.

3. Epoxy resin was injected into the space between P1 and the glulam. After the epoxy resin hardened, the specimen was reversed. Then epoxy resin was injected into the space between P2 and the glulam.

In addition to the above process, Steel tubes $\mathrm{P} 1^{*}$ and $\mathrm{P} 2 *$, whose outer and inner diameters were $25 \mathrm{~mm}$ and $18 \mathrm{~mm}$, were inserted as shown in Fig. 6(b) in this experiment to eliminate the difference between the inner diameter of the washer and those of $\mathrm{P} 1$ and $\mathrm{P} 2$. Note that these additional steel tubes, $\mathrm{P} 1 *$ and $\mathrm{P} 2 *$, were unnecessary if the inner diameter of the washer had been equal to those of P1 and P2.

The cross section and length of the Douglas-fir glulam were $390 \mathrm{~mm} \times 150 \mathrm{~mm}$ and $800 \mathrm{~mm}$, respectively. The grade of the glulam was $10.5 \mathrm{GPa}$ in Young's modulus and 
30.0 MPa in flexural strength. The average moisture content and density of the glulam measured were $11.1 \%$ and $488 \mathrm{~kg} / \mathrm{m}^{3}$, respectively. The grade and the thickness of the aluminum splice plates were A2017P (JIS H4000) ${ }^{10}$ and $12 \mathrm{~mm}$. Curved slots, or curved elongated holes, of $18 \mathrm{~mm}$ width were predrilled to the splice plates as shown in Fig. 3 so that the allowable relative rotation angle was equal to $1 / 20$ radian. No surface treatment was performed to the aluminum splice plate. Note that, although aluminum was selected as a material for the splice plates in this paper to realize smooth sliding, ${ }^{11}$ other materials can be used as far as smooth sliding is obtained. The grade of all the steel tubes was SS400 (JIS G3101). ${ }^{12}$ The grade and diameter of the high strength bolts were F10T (JIS B1186) ${ }^{13}$ and $16 \mathrm{~mm}$. The grade of the epoxy resin was $9.1 \mathrm{MPa}$ in shear bond strength. The steel tubes were soaked into hydrochloric acid for 12 hours as a surface treatment for increasing the bond strength. The average friction coefficient $\mu$ between the end surfaces of the steel tube and the aluminum splice plate was obtained as 0.30 from the material tests.

Cyclic horizontal forced displacement was applied at the top of the glulam using a hydraulic actuator as shown in Figs. 1 and 2. The amplitude $\psi$ of the forced displacement was increased as 1.67, 3.33, 6.67, 13.33, and $20.00 \mathrm{~mm}$, where 3 cycles of loading was repeated in each value of amplitude. The value of amplitude was determined so that $\psi / h$ corresponds to $1 / 240,1 / 120,1 / 60,1 / 30$, and 1/20 radian, where $h(=400 \mathrm{~mm})$ is the distance between the position of the actuator and the center of rotation as illustrated in Fig. 1. The loading rate of the forced displacement was 0.1 $\mathrm{mm} / \mathrm{sec}$. The aluminum splice plates and the box section steel pipes were fixed to the reaction floor as shown in Fig. 1.

Fig. 3(b) schematically depicts the measurement of the relative rotation angle $\theta$ between the glulam and the aluminum splice plate. The laser displacement sensors were 
fixed to the aluminum splice plate as shown in Fig. 2. The relative rotation angle $\theta$ can be obtained as

$$
\theta=\frac{u_{1}-u_{2}}{d}
$$

where $u_{1}$ and $u_{2}$ indicate respectively the displacement measured by the laser displacement sensors 1 and 2 , and $d$ is the distance between the two laser displacement sensors. The values of $d$ were $255 \mathrm{~mm}$ and $165 \mathrm{~mm}$ for Specimens A1 and A2, respectively. In addition, displacement sensors were placed to measure the relative displacement between the aluminum splice plates and the box section steel pipes as shown in Fig. 2 to ensure no relative displacement takes place between the aluminum splice plates and the box section steel pipes. The applied moment $M$ was obtained as

$$
M=P h,
$$

where $P$ is the applied horizontal load measured by the load cell mounted to the actuator as shown in Figs. 1 and 2. As shown in Fig. 2(b), the bolt tension was monitored by using the strain gage attached inside the hole drilled at the center of the high strength bolts. ${ }^{6}$

\section{Results and discussions}

Figs. 7 and 8 illustrate the relationship between the applied moment $M$ and the relative rotation angle $\theta$ between the glulam and the splice plates. The estimates of the moment capacity $M_{c}$ are also shown by dotted lines in Figs. 7 and 8. For Specimens A1 and A2, $M_{c}$ was $26.5 \mathrm{kNm}$ and $28.6 \mathrm{kNm}$, respectively. These values were obtained as 


$$
M_{c}=n \mu T R,
$$

where $n$ is the number of high strength bolts, $\mu(=0.30)$ is the average friction coefficient between the aluminum splice plates and the end surfaces of the steel tubes obtained from the material tests, $T$ is the average value of the bolt tension measured before the quasistatic cyclic loading test, and $R$ is the distance between the center of rotation and the locations of the steel tubes as shown in Fig. 5.

Figs. 9 and 10 show the Specimens A1 and A2 after the test. It should be noted that the cracks in Specimen A2 were minute and a black marker pen was used to indicate their locations in Fig. 10. On the other hand, the cracks in Specimen A1 were clearly visible and no marker pen was used to indicate their locations in Fig. 9. Fig. 11 shows the splice plates after the tests, from which traces of slip can be clearly seen.

Table 1 summarizes the variations of the equivalent viscous damping ratio. The equivalent viscous damping ratio is obtained as

$$
\varsigma_{e q}=\frac{1}{4 \pi} \frac{E_{h}}{E_{e}}
$$

where $E_{h}$ is the energy dissipated in one cycle of hysteresis loop and $E_{e}$ is the strain energy at the maximum rotation angle in the hysteresis loop. Note that $E_{e}$ is defined by using the secant modulus.

From the tests, the following observations and discussions can be made.

1. Pinching was successfully avoided and nearly rigid-plastic hysteresis loops with high equivalent viscous damping ratio were obtained in both Specimens A1 and A2.

2. The strength capacity ratio, defined as the ratio of the maximum flexural stress corresponding to $M_{c}$ to the flexural strength of the glulam, were $28.3 \%$ and $30.1 \%$, respectively, for Specimens A1 and A2. For reference, the ratio of the shear stress to the maximum flexural stress was $16.3 \%$ for each specimen. 
3. Although partial fracture took place in the glulam as shown in Figs. 9 and 10, no significant drop of restoring moment can be observed in the hysteresis loops. This means that the failure mode of the present connection was ductile.

4. The measured value of the amplitude of rotation angle was significantly smaller than the intended value of the amplitude of rotation angle $\psi / h$. Possible reasons of the difference are (1) the variation of the center of rotation due to the clearance between the high strength bolts and the curved slots and (2) the deformation of the glulam. To resolve the problem, it seems effective to provide a pin connection at the center of rotation. $^{3,5}$

5. Unexpected hardening was observed when sliding took place even though the relative rotation angle was smaller than the allowable one. And the moment capacities obtained by the tests were slightly lower than the estimates. Possible reasons of the unexpected hardening and the lower moment capacities are (1) the interaction between shear force and moment, and (2) the friction between the side of the high strength bolts and that of the slots in the splice plates. Providing a pin connection at the center of rotation may also resolve these problems.

\section{Conclusions}

This note examined the feasibility of an improved slotted bolted connection for timber moment frames. The hysteresis loops obtained from the quasistatic cyclic loading tests of the two connection specimens were nearly rigid-plastic whose equivalent viscous damping ratio was more than $30 \%$ in the ranges of rotation angle close to or over $1 / 50$ radian. Although unexpected hardening was observed during the sliding phase, the 
experimental results demonstrate the feasibility and potential of the present connection.

The main strengths of the present improved SBC for timber moment frames can be summarized as follows: (1) Compression due to bolt tension is fully supported by steel tubes, which prevents the reduction of the energy dissipating capacity due to shrinkage of glulam even in long term use. (2) Initial stiffness is very high when a timber frame is under normal condition or subjected to small to moderate earthquakes. On the other hand, stable and large energy dissipation by sliding between steel tubes and aluminum splice plates can be expected when a timber frame is subjected to strong earthquakes.

The issues that need to be addressed in the future include, but not limited to, the examination of the effect of providing a pin connection at the center of rotation, further improvement of the build up process, and more comprehensive study of the design conditions for preparing a design guideline of the present SBC.

\section{Acknowledgements}

This research was supported by Emachu research grant (2009-2010) provided by the Japan Wood Research Society. Mr. Nobutoshi Yoshida, a technical engineer of Kyoto University, helped to conduct the experiments. These supports are gratefully acknowledged. Also the authors appreciate the comments from the reviewers, which led to significant improvements of the draft of this paper. 


\section{References}

1. Rodd PD (1988) Timber joints made with new and improved circular dowel connectors. In: Proc. Int. Timber Engineering Conference, Seattle, Washington State University 1:26-37

2. Guan ZW, Rodd PD (2001) Hollow steel dowels - a new application in semi-rigid timber connections. Eng Struct 23:110-119

3. Leijten AJM, Ruxton S, Prion H, Lam F (2006) Reversed-cyclic behavior of a novel heavy timber tube connection. J Struct Eng 132:1314-1319

4. Thelandersson S, Larsen HJ (2009) Timber Engineering. Wiley. West Sussex, UK.

5. Duff SF, Black RG, Mahin A, Blondet M (1998) Friction damped energy dissipation timber connections. In: Proceedings of the 5th World Conference on Timber Engineering, Montreux, Switzerland, 1:361-368.

6. Leichti RJ, Tjahyadi A, Bienhaus A, Gupta R, Miller T, Duff, S (2002) Design and behavior of friction dampers for two-dimensional braced and moment-resisting timber frames. In: Proceedings of the 7th World Conference of Timber Engineering, Shah Alam, Malaysia, 3:267-274

7. Awaludin A, Hirai T, Hayashikawa T, Sasaki Y, Oikawa A (2008) One-year stress relaxation of timber joints assembled with pretensioned bolts. J Wood Sci $54: 456-463$

8. Tokuda H, Shigematsu, Y, Kondo K (1990) Timber space structures of "the Japanese government plaza" in the international garden and greenery exposition Osaka, Japan, 1990 (in Japanese), GBRC 59:3-8

9. Suzuki T, Sakata H, Takeuchi T, Matsuoka Y, Nagayama K, Matsuda K (2005) Study on mechanical behavior of glulam timber-steel composite member (in 
Japanese) In: Summary of Technical Papers of Annual Meeting of AIJ, C-1:277-278

10. Japanese Industrial Standard Committee (2006) JIS H4000 (in Japanese), http:// www.jisc.go.jp/app/pager?id=59411, Accessed August 21, 2010

11. Yoshioka T, Ohkubo M (2003) Bending-shear tests of wide flange steel beam using the bolted frictional-slippage damper on the bottom flange at the beam end (in Japanese), AIJ J Struct Constr Eng 68(573):177-184

12. Japanese Industrial Standard Committee (2010) JIS G3101 (in Japanese), http:// www.jisc.go.jp/app/pager?id=60578, Accessed August 21, 2010

13. Japanese Industrial Standard Committee (2007) JIS B1186 (in Japanese), http:// www.jisc.go.jp/app/ pager?id=60898, Accessed August 21, 2010 


\section{List of figures}

Fig. 1. Test setup of Specimen A1.

Fig. 2. Photograph of Specimen A1. (A: Douglas-fir glulam, B: Aluminum splice plate, C: Box section steel pipe, D: Load cell, E: Laser displacement sensors, F: Displacement sensors)

Fig.3. Configurations of the specimen: (a) Initial configuration. (b) Deformed configuration.

Fig. 4. Schematics of resin injection between steel tube and glulam.

Fig. 5. Locations of the steel tubes: (a) Specimen A1. (b) Specimen A2.

Fig. 6. Cut open specimen.

Fig. 7. Moment-relative rotation angle relationship for Specimen A1.

Fig. 8. Moment-relative rotation angle relationship for Specimen A2.

Fig. 9. Specimen A1 after the test.

Fig. 10. Specimen A2 after the test.

Fig. 11. Splice plates after the tests: (a) Specimen A1. (b) Specimen A2. 
Manuscript submitted for publication in Journal of Wood Science

Feasibility of improved slotted bolted connection for timber moment frames

by Y. Araki, T. Endo, M. Iwata
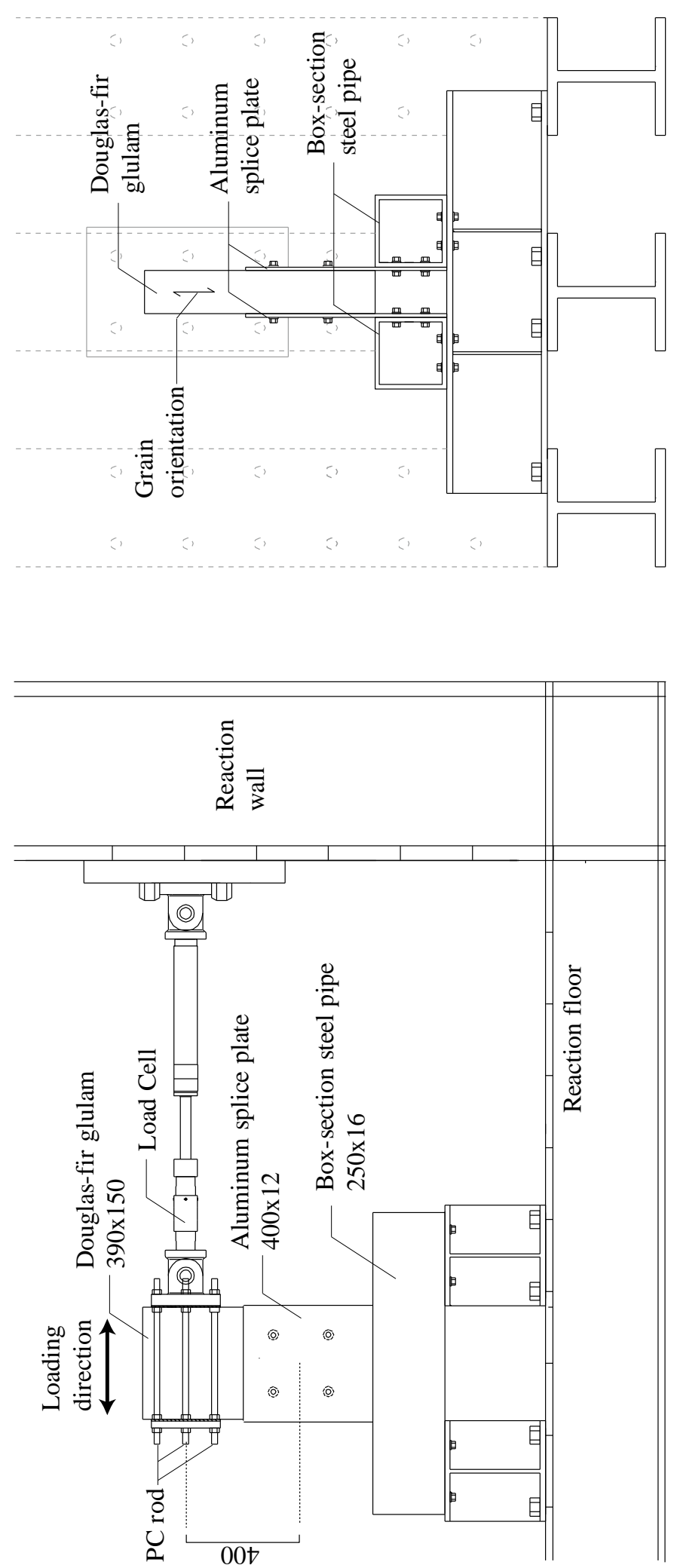

Fig. 1. 


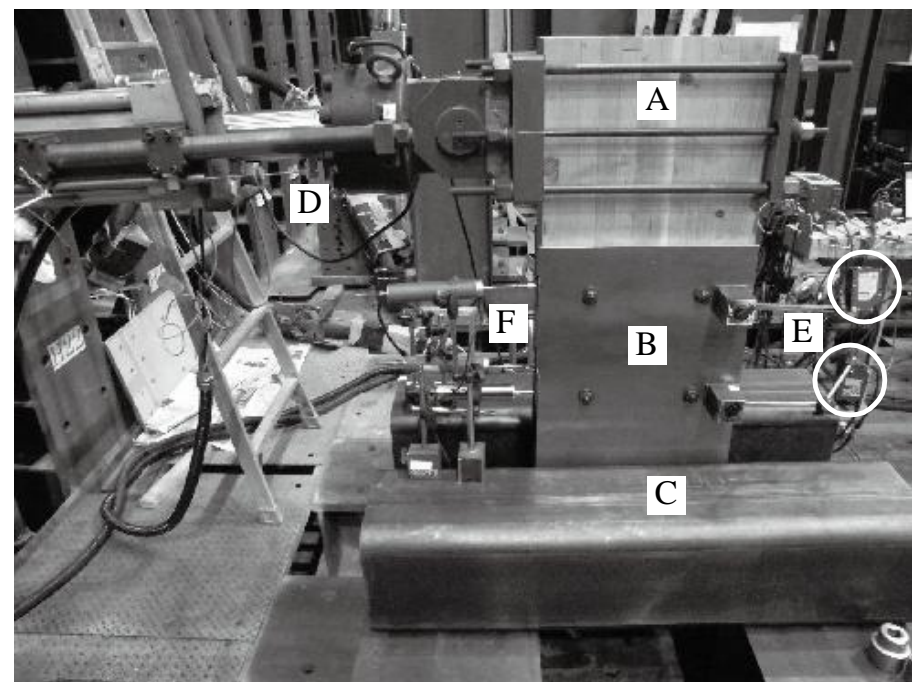

(a)

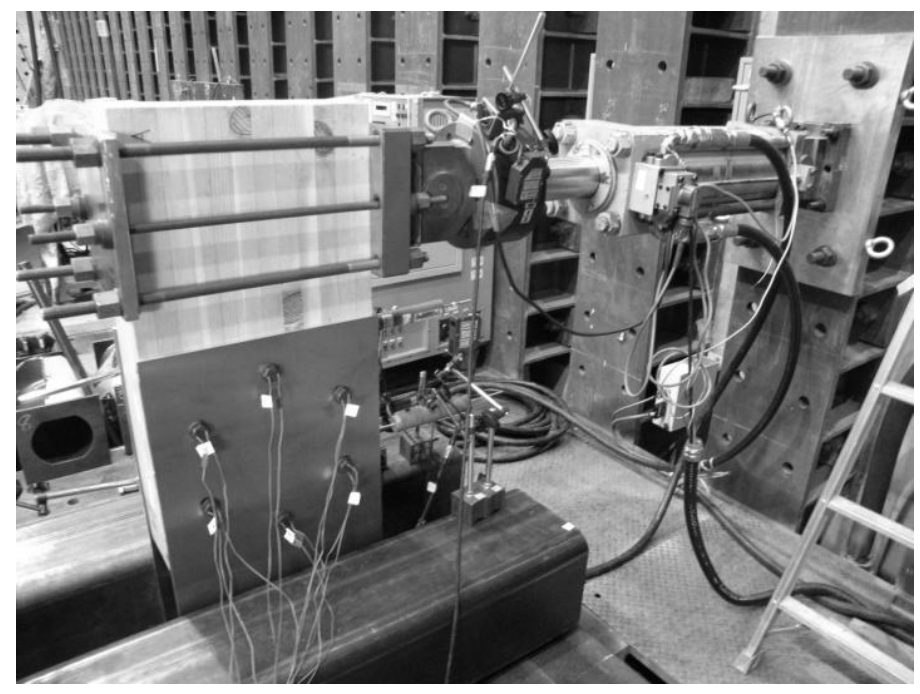

(b)

Fig. 2. 
Manuscript submitted for publication in Journal of Wood Science

Feasibility of improved slotted bolted connection for timber moment frames by Y. Araki, T. Endo, M. Iwata

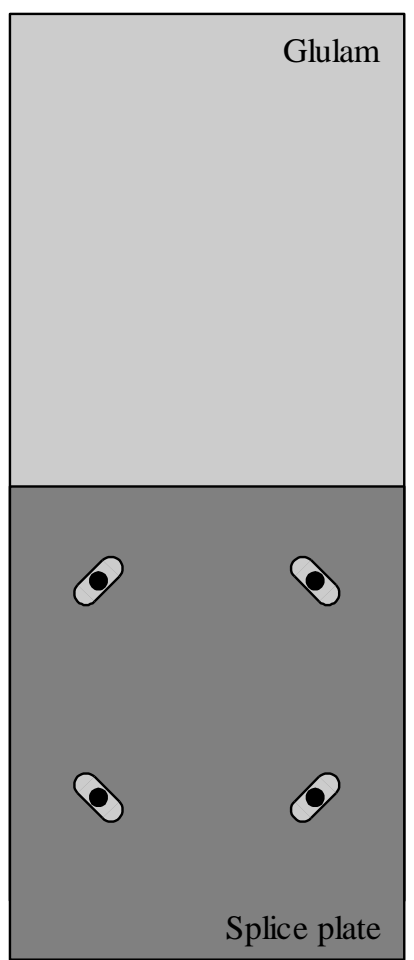

(a)

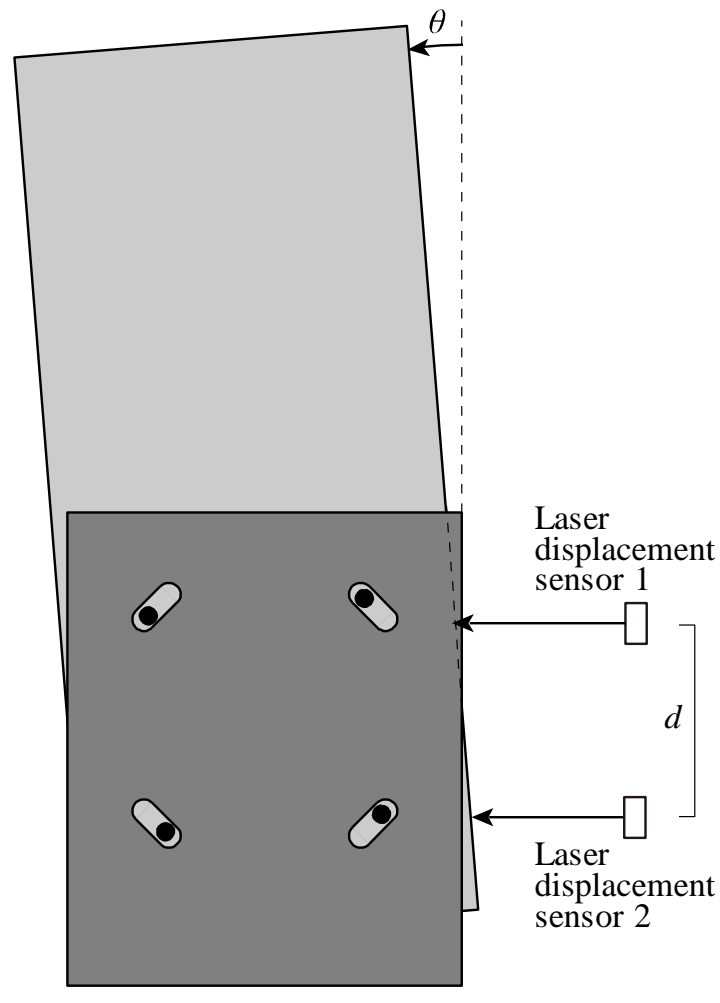

(b)

Fig. 3. 
Manuscript submitted for publication in Journal of Wood Science

Feasibility of improved slotted bolted connection for timber moment frames

by Y. Araki, T. Endo, M. Iwata

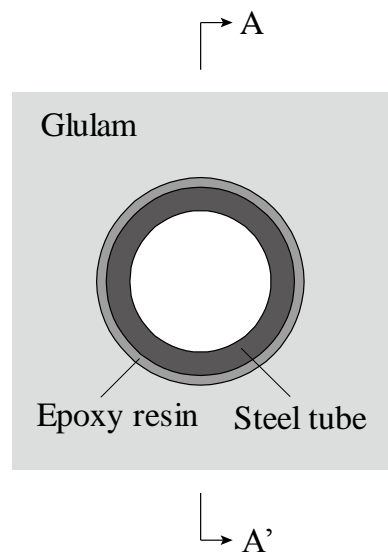

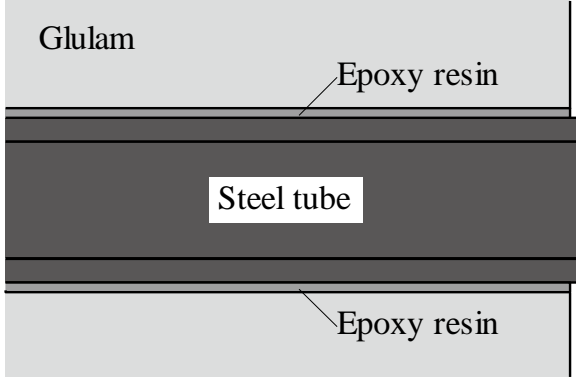

A-A' section

Fig. 4. 
Manuscript submitted for publication in Journal of Wood Science

Feasibility of improved slotted bolted connection for timber moment frames

by Y. Araki, T. Endo, M. Iwata

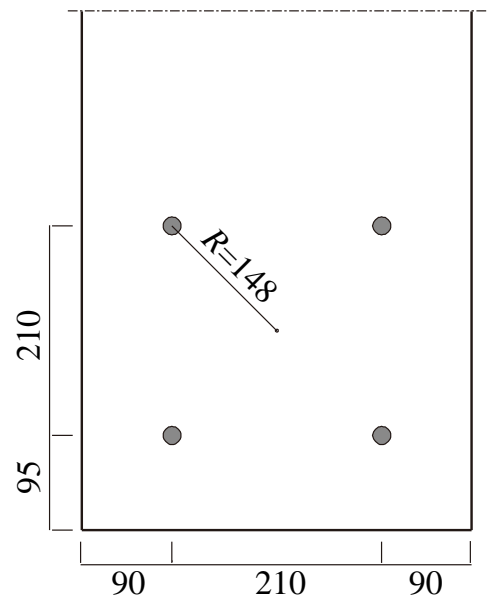

(a)

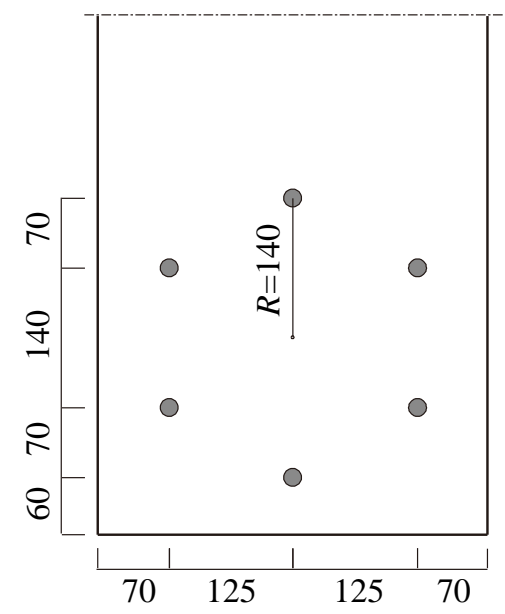

(b)

Fig. 5. 
Manuscript submitted for publication in Journal of Wood Science

Feasibility of improved slotted bolted connection for timber moment frames

by Y. Araki, T. Endo, M. Iwata

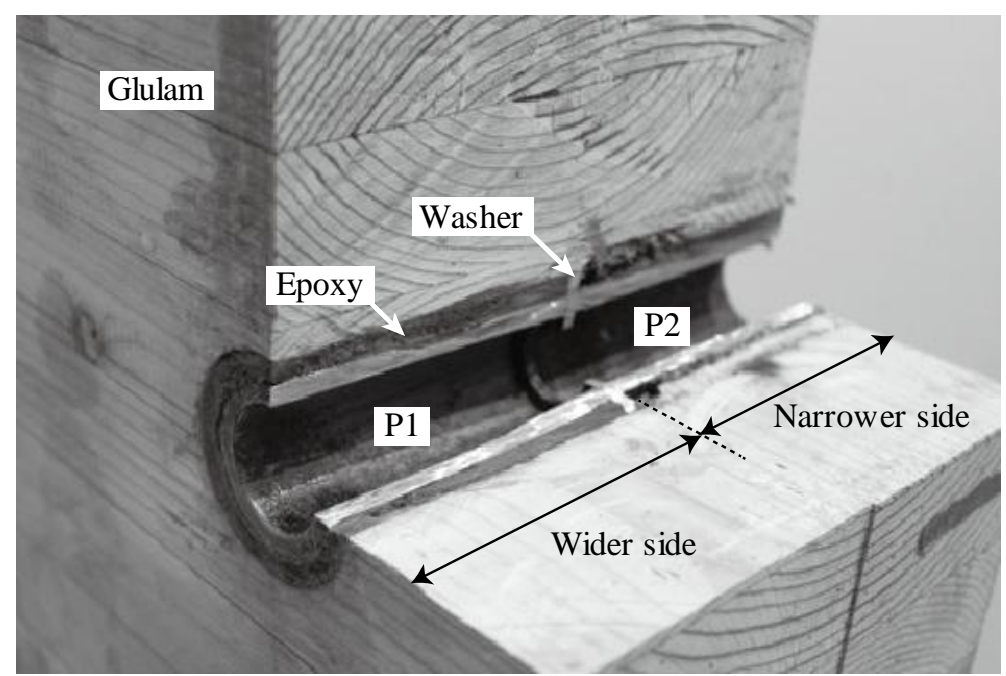

(a)

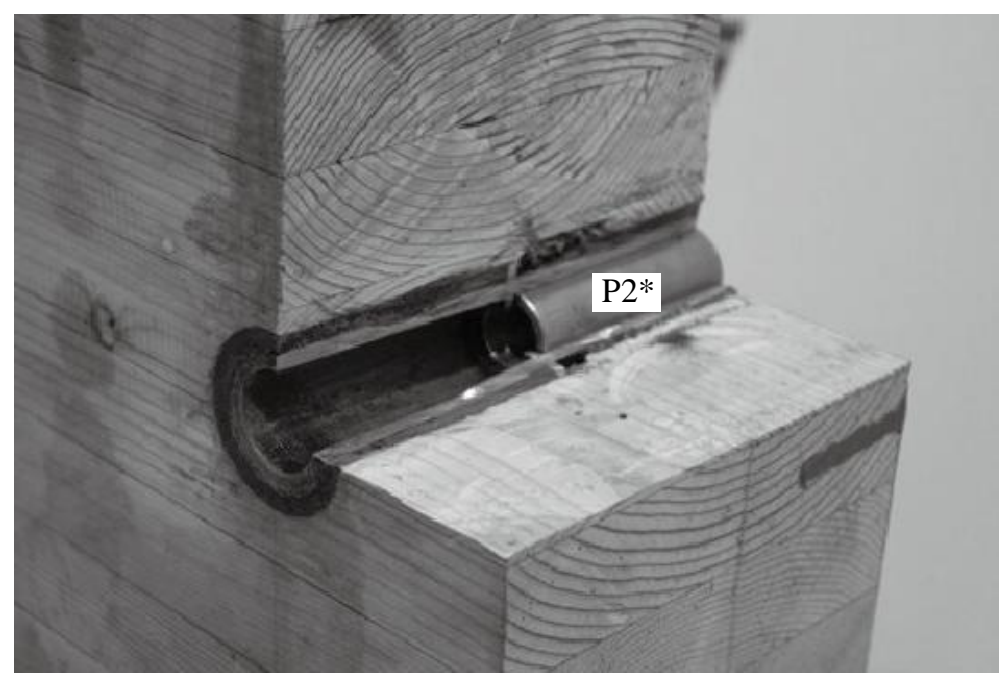

(b)

Fig. 6. 


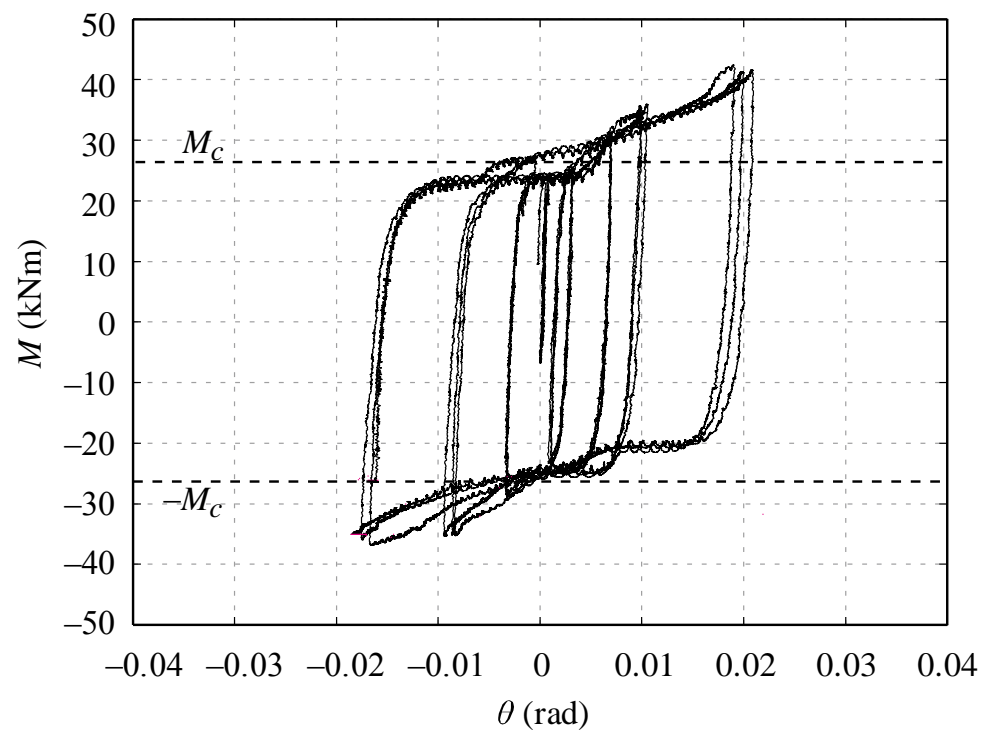

Fig. 7. 


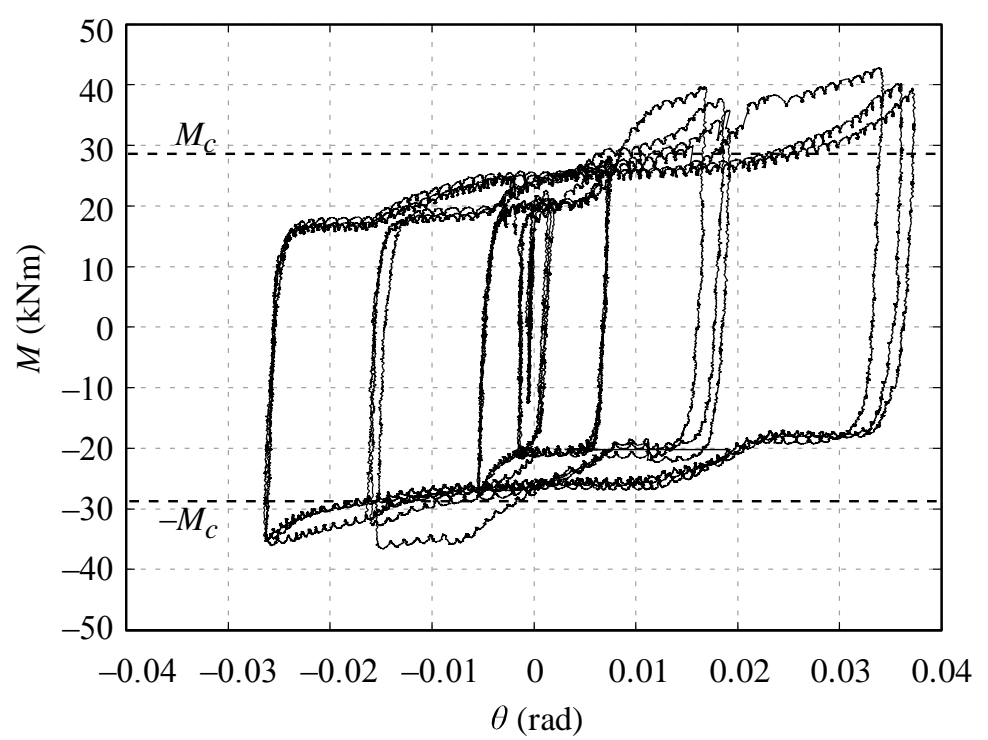

Fig. 8. 
Manuscript submitted for publication in Journal of Wood Science

Feasibility of improved slotted bolted connection for timber moment frames by Y. Araki, T. Endo, M. Iwata

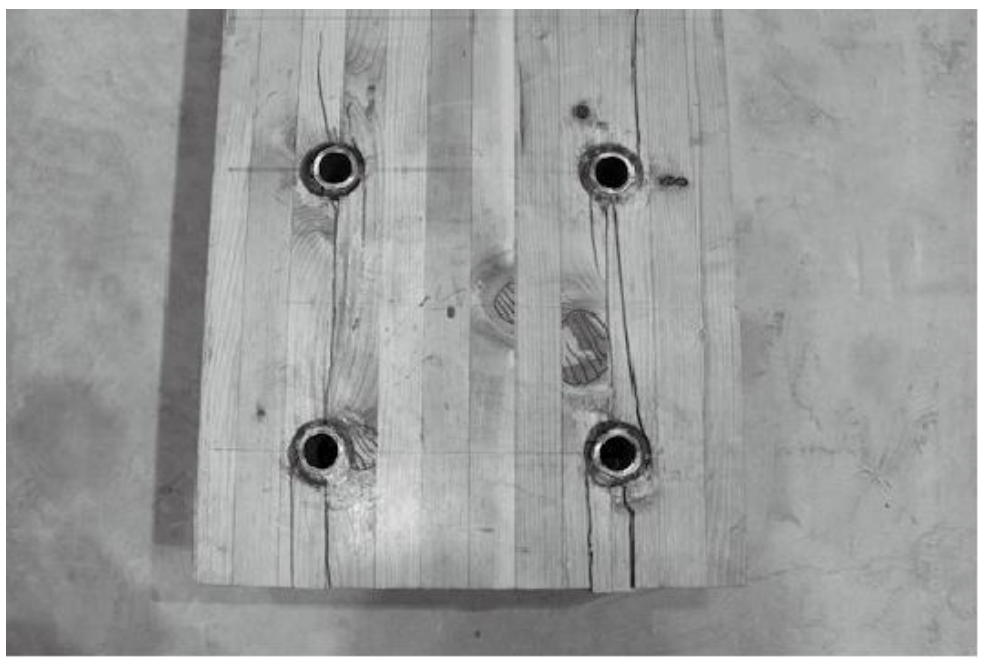

(a)

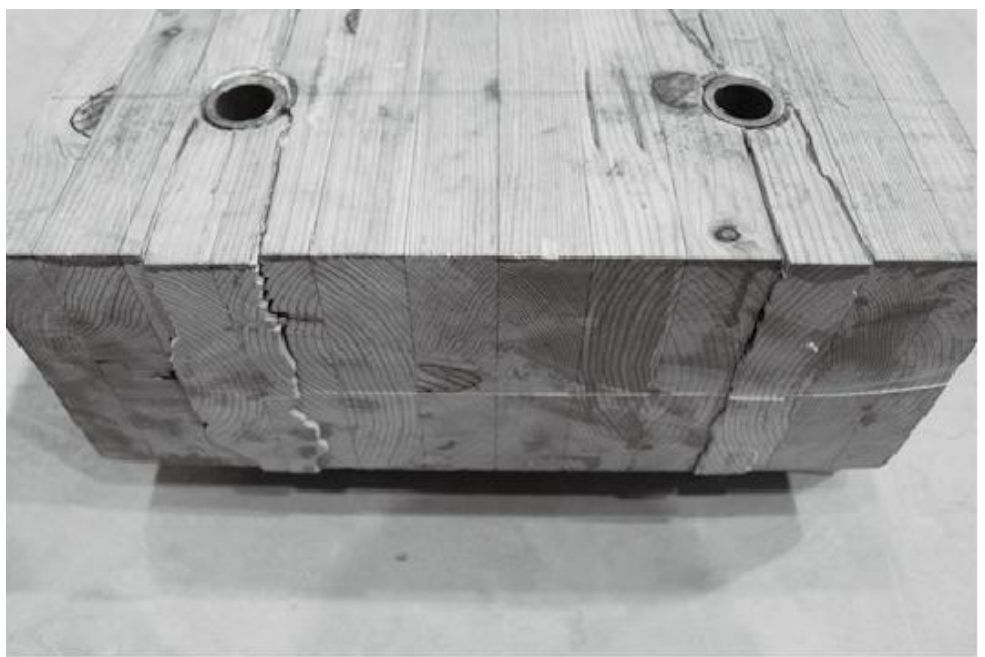

(b)

Fig. 9. 
Manuscript submitted for publication in Journal of Wood Science

Feasibility of improved slotted bolted connection for timber moment frames

by Y. Araki, T. Endo, M. Iwata

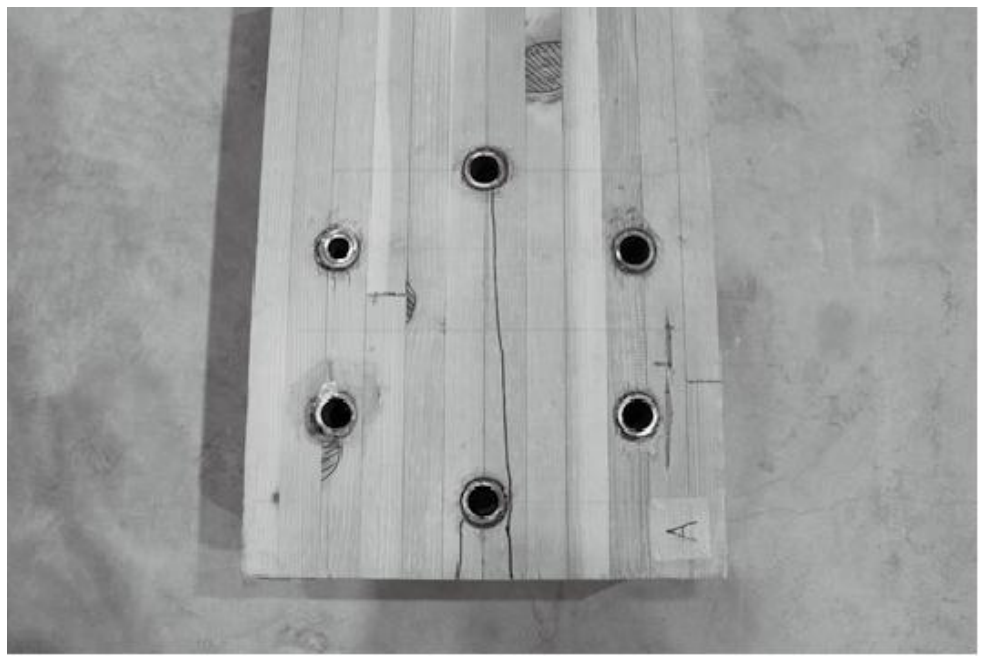

(a)

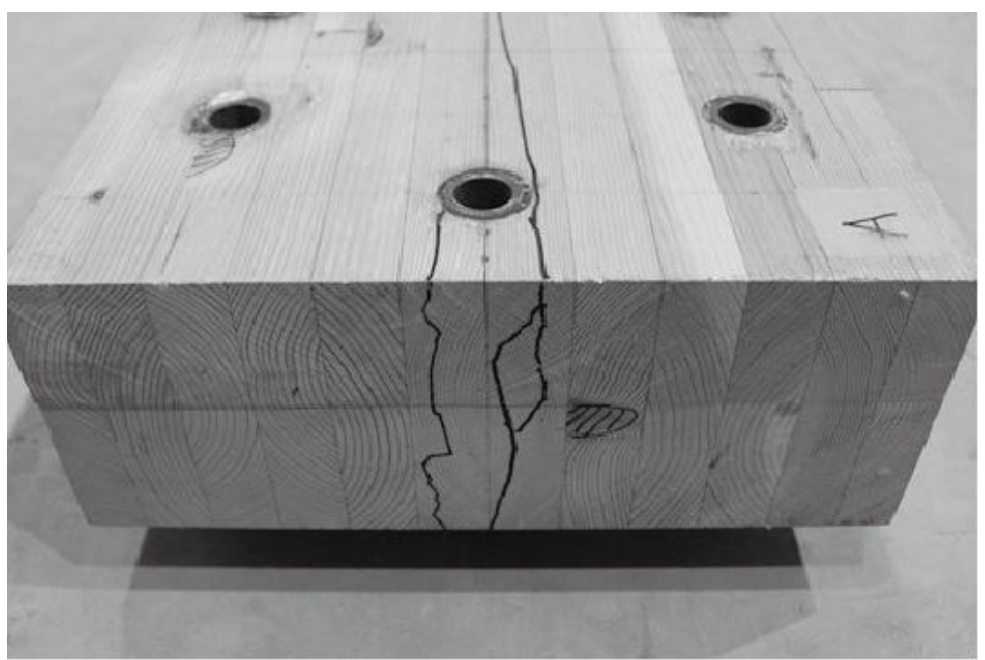

(b)

Fig. 10 . 
Manuscript submitted for publication in Journal of Wood Science

Feasibility of improved slotted bolted connection for timber moment frames

by Y. Araki, T. Endo, M. Iwata

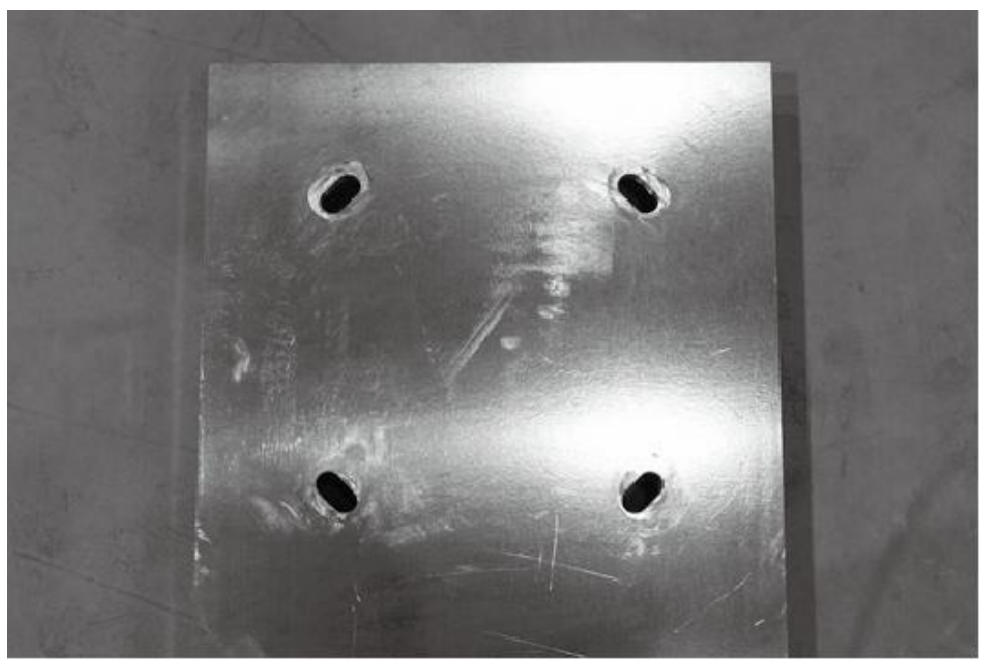

(a)

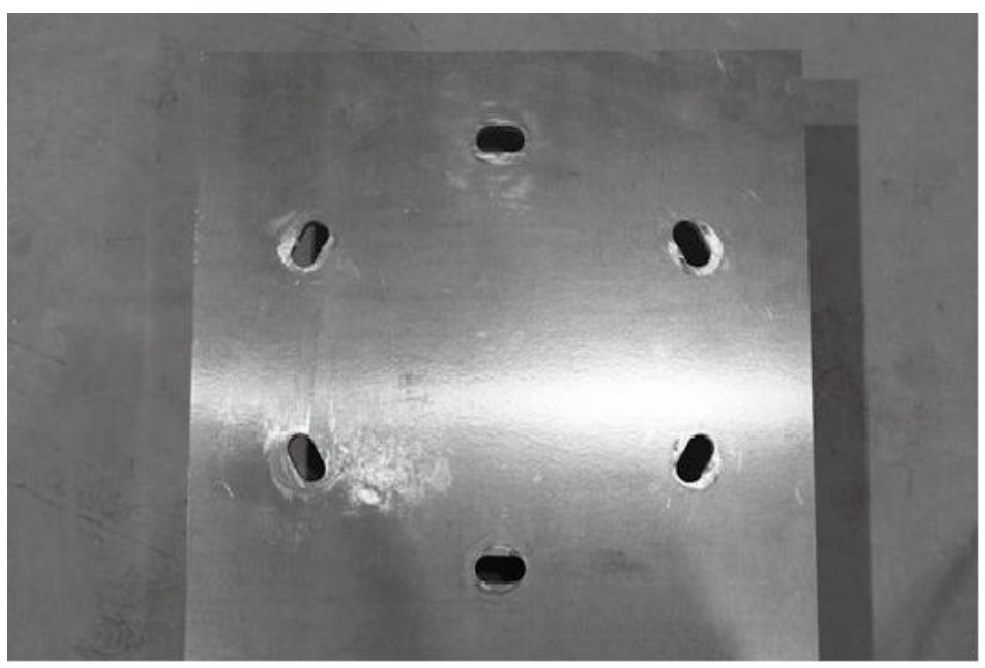

(b)

Fig. 11. 
Manuscript submitted for publication in Journal of Wood Science

Feasibility of improved slotted bolted connection for timber moment frames

by Y. Araki, T. Endo, M. Iwata

\section{List of tables}

Table 1. Variations of equivalent viscous damping ratio. 
Table 1.

\begin{tabular}{|c|c|c|c|c|c|c|c|c|c|c|c|c|c|}
\hline \multirow{2}{*}{\multicolumn{2}{|c|}{$\begin{array}{c}\psi \\
\text { cycle }\end{array}$}} & \multicolumn{3}{|c|}{3.33} & \multicolumn{3}{|c|}{6.67} & \multicolumn{3}{|c|}{13.33} & \multicolumn{3}{|c|}{20.00} \\
\hline & & 1 & 2 & 3 & 1 & 2 & 3 & 1 & 2 & 3 & 1 & 2 & 3 \\
\hline \multirow[b]{2}{*}{$\varsigma_{\text {eq }}$} & $\mathrm{Al}$ & 48.8 & 34.4 & 31.6 & 36.8 & 43.7 & 43.5 & 43.0 & 43.1 & 41.3 & 32.3 & 32.9 & 33.9 \\
\hline & A2 & 45.0 & 49.4 & 44.9 & 39.8 & 43.3 & 41.8 & 38.1 & 38.2 & 41.5 & 35.7 & 36.3 & 36.8 \\
\hline
\end{tabular}

$\psi(\mathrm{mm})$ : loading amplitude, $\boldsymbol{S}_{e q}(\%)$ : equivalent viscous damping ratio. 